\title{
Applications of Technology for Small Holders' Livestock to Meet Global Food Production
}

\author{
Max F. Rothschild ${ }^{1}$ and Graham Plastow ${ }^{2}$
}

\begin{abstract}
While the Green Revolution greatly changed production of crops worldwide and helped feed over a billion people, improved production of livestock has been more limited across the globe. Modern advances in livestock production have in general only benefitted two groups: large scale livestock producers and consumers in the developed world. In some parts of the world many of the animal production practices have not changed for the last 1000 years and in other regions small holders have benefited only marginally by the scientific advances that now are an integral part of large scale commercial production. However, increased food insecurity and a worldwide food production crisis loom in the future as the most significant scientific challenge facing us in the next 30 years. Expectations are that human population growth will soon go from 7.3 billion to 9.6 billion by 2050, and food production must increase rapidly to meet the demand. These increases must come despite evidence of climate change and limited land and water resources. Whilst there is a perception of over consumption of animal products in the developed world, there are still significant numbers that are undernourished. Animal protein plays a very important role in achieving a balanced diet in the developing world, especially for the adequate nutrition of children. Furthermore, it is expected that significant increased demand for animal source foods will occur especially in the poorer countries of the developing world where most livestock are produced by small holders, but also in countries like China and Brazil which are transforming quickly. Many researchers have touted that modern feeding systems, and the use of advanced reproductive technologies and advanced genetics and genomics will provide solutions to increasing food in the developing world. These opportunities certainly exist, but direction and focus of research, funding issues, human capacity training and training of small holders will all be required for increasing livestock production to satisfy these demands. These activities will need to be embedded within sustainable programs that address implementation from the outset, and benefiting small holder production will be crucial to meeting this challenge.
\end{abstract}

Key words: Animal production, developing world, food insecurity, small producers.

\section{Aplicaciones de Tecnología en el Ganado de Pequeños Productores para Satisfacer la Demanda Global de Alimento}

Resumen. Mientras que la llamada Revolución Verde ha producido grandes cambios en la producción agrícola en el mundo, lo que ha ayudado a alimentar a más un billón de personas, mejoramientos en la ganadería han sido más limitados. Los adelantos modernos en la producción de ganado en general han beneficiado sólo a dos grupos: los ganaderos de gran escala y los consumidores en los países desarrollados. En algunas partes del mundo, muchas de las prácticas de producción animal no han cambiado en los últimos 1000 años y en otras regiones los pequeños productores se han beneficiado sólo marginalmente por los avances científicos que ahora son una parte integral de la producción comercial a gran escala. Sin embargo, el aumento en la inseguridad por la procura de alimentos y una crisis en la producción mundial de alimentos surgen como el reto científico más desafiante al que nos enfrentamos en los próximos 30 años. Las expectativas del crecimiento de la población humana de 7.300 millones a 9.600 millones para el año 2050, requiere que la producción de alimentos aumente rápidamente para satisfacer la demanda. Estos aumentos deben ocurrir a pesar de la evidencia del cambio climático y la escasez de tierras y recursos hidráulicos. A pesar de que existe una percepción de sobreconsumo de productos animales en el mundo desarrollado, existen todavía índices significativos de desnutrición. La proteína animal juega un papel importante en la obtención de una dieta balanceada en países in vías de

\footnotetext{
${ }^{1}$ Department of Animal Science, lowa State University, Ames, lowa, United States, 50011. Email mfrothsc@iastate.edu

${ }^{2}$ Department of Agricultural, Food and Nutritional Science, University of Alberta, Edmonton AB, T6G2C8 Canada. Email plastow@ualberta.ca
} 
desarrollo, especialmente para la nutrición adecuada de la niñez. Además, se espera una creciente demanda de alimentos de origen animal, especialmente en los más pobres de los países en vías de desarrollo, donde la mayoría del ganado es propiedad de pequeños productores, pero también en países como China y Brasil, los que se están transformando rápidamente. Muchos investigadores han planteado sistemas modernos de alimentación, y utilización de tecnologías avanzadas de reproducción y de genética y genómica para proporcionar soluciones para aumentar la alimentación humana en países en vías de desarrollo. Ciertamente estas oportunidades existen, pero la orientación y el enfoque de la investigación, financiamiento, capacitación de personal, y entrenamiento de pequeños productores, constituyen requisitos necesarios para llevar a cabo el incremento de la producción ganadera necesario para satisfacer estas demandas. Para afrontar este reto, estas actividades tendrán que ser incorporadas dentro de programas sostenibles enfocados desde el inicio en su ejecución, y en el beneficio de los pequeños productores.

Palabras clave: Inseguridad alimentaria, mundo en desarrollo, pequeños productores, producción animal.

\section{Introduction}

For many applied crop and livestock researchers, the greatest scientific and moral challenge of the $21^{\text {st }}$ century likely will be the challenge of feeding the growing human population. It has been estimated that nearly 800 million people suffer from daily hunger and that as many as an additional 1.5 billion people have food insecurity issues (Smith et al. 2013). Estimates further suggest the global population will grow from over 7.4 billion people (at time of publication, http://www.worldometers.info/world-population) to approximately 9.6 billion people in 2050, and food production will have to increase by an additional $70 \%$ of today's production (Ingram et al. 2010). This, of course, will come with limited land and water availability.

Growth in population numbers and increases in Gross Domestic Product (GDP) have fueled a livestock revolution (Delgado et al. 1999) since the 1970s. Total meat consumption has tripled worldwide from 1980 to 2002 (World Bank 2009). In the developing world total meat consumption is expected to double between now and 2050 as will milk consumption, while in the developed world both meat and milk consumption are likely to increase by less than $15 \%$ (Thorton 2009). The importance of animal protein in relation to balanced nutrition and its role in the future is well described in the review by Ludu and Plastow (2013). Meat is a rich source of readily available nutrients such as iron, vitamin B12 and fatty acids (Rothschild and Steinfeld 2014, Gupta 2016).

Given the present day limited production efficiency of livestock in the developing world drastic increases in production levels and efficiency will be required to meet these demands. These increases can be accomplished by increasing livestock numbers very significantly-but with enormous environmental as well as production issues/impacts-or by increasing production efficiency per animal. A challenge of similar magnitude was met in the developed world (and some advanced developing countries like China and Brazil) over the last 75 years, although without the extra constraints of reducing resources (land, water, energy) and the impact of climate change. These increases in production efficiency have been accomplished in the developed world, in large part, by improvements in the technologies that are integral to animal production and in the adoption of ad libitum feeding in most developed countries. The impact of these efforts, especially genetics, is beautifully demonstrated in chickens (Havenstein et al. 2003) and pigs (Fix et al. 2010) and has been reviewed by others (Hume et al. 2011). However for the developing world, while industrial production is likely to increase it must be accompanied by meeting livestock demand by transforming smallholder and pastoral livestock systems. As Rothschild and Steinfeld (2014) point out, livestock provide other resources in these environments including manure and draft power as well as financial security.

This paper is in no way meant to be an exhaustive review of all opportunities and difficulties that exist in this area. Rather, the objectives are to define some of the opportunities to use existing and new technologies and to address some of the limitations facing use of improved technologies in the developing world by small holders (pequeños productores). Given the authors' backgrounds much of the discussion will be centered on genetics and genomics. 


\section{Use of Existing Technologies}

In the $20^{\text {th }}$ century, increases in production traits in all major livestock species have taken place in developed countries largely due to 1) improved nutrition, 2) ad libitum availability of water and feed, 3) increases in genetic merit resulting from genetic improvement programs using advanced quantitative genetic methodology, 4) improved reproductive technologies including wide spread use of artificial insemination (Al) and embryo transfer, and 5) improvements in animal health and disease control (including biosecurity as well as the development of vaccines and other treatments). Some of these technologies are listed in Table 1 . It seems that in many cases the need for innovation leads to a focus on applying the latest technologies to problems. This approach may not always be the most effective, especially if they require advanced training, cultural considerations and infrastructure. Instead, there should be some consideration of human aspects and adoption of tried approaches such as modifying existing solutions to the needs of the target producers. They may not always grab headlines, or funding, but they can make significant incremental improvement and real impact where it is needed.

\section{Feed Technologies to Improve Production}

In modern commercial systems, especially for nonruminants, feed costs often exceed over $40 \%$ of the production cost and the two largest feeding factors affecting these costs are 1) quality of the feed, and 2) availability of sufficient amounts of feed. For small holders these represent considerable challenges except for ruminant production where and when small holders have access to good forage. For other small holders, especially those in peri-urban settings, the cost and availability of sufficient quality feed is extremely constraining. For ruminants, many small holders are left to chop grasses and forages from the roadside or from nearby open lots. Other small holders owning chickens or pigs often let the animals scavenge and this causes real biosecurity concerns. Many small holders do not fully understand the concept of growth and hence to make purchased feeds to last longer they feed at levels that maintain the animal's weight and do not provide the needed feed for increased growth and weight gain. Also improved/formulated feeds, premixes, mineral and vitamin supplements are not affordable for most small producers in developing countries. Additionally, considerable nutrition advice is required for small holders and clearly extension workers with nutritional training would be advantageous to help in ration formulation, and other assistance. If these existing technologies could be transferred at a sustainable and affordable manner, then major increases in efficiency could be achieved and food security and economic growth among small holders would be improved.

Table 1. New and improved technologies for improved commercial animal production.

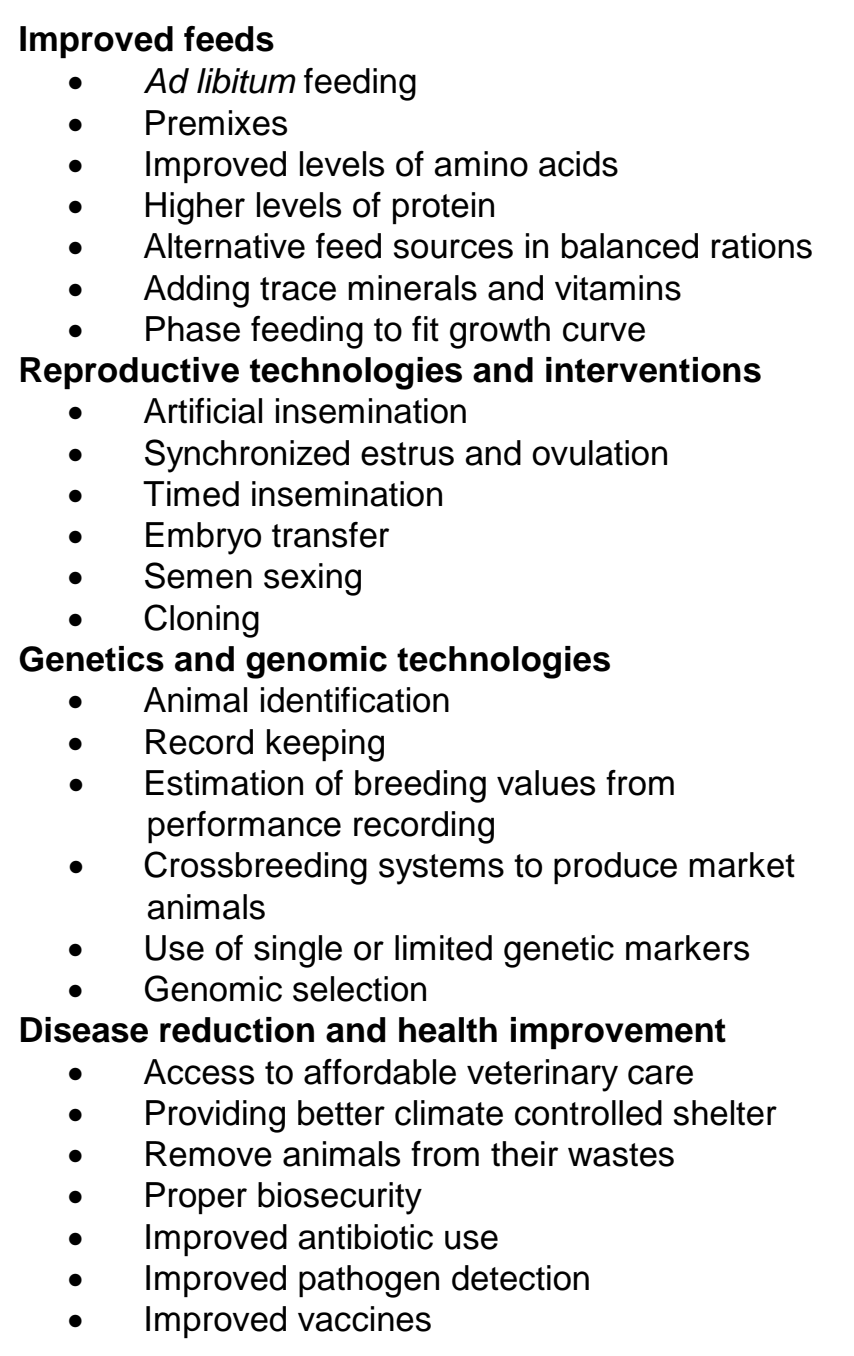




\section{Genetics and Genomics for Livestock Production}

Artificial selection began with domestication some 10-12,000 years ago, and development of breeds, especially those suited for small holders and livestock keepers, followed. Such developments depended heavily on selection and other genetic tools practiced by master breeders and indigenous people. For the developed world, adoption of other animal genetics practices such as animal identification, record keeping, selection of fast growing animals to be future parents and the adoption of mating systems such as crossbreeding for heterosis have been highly effective. Unfortunately many of these standard practices are not followed or poorly adhered to in the rest of the world. For example, in many locations where improved livestock are donated by aid agencies local breeders may use them repeatedly, ignoring inbreeding. Also, given market pressures, small holders often sell the fast growing animals first instead of selecting and retaining them as future improved parents. Clearly, many of these issues could be resolved with a major education effort to improve the information and its application to specific breeding plans. One attempt at this is the Community Based Breeding Programs (CBBP) which have sprung up thanks to some governmental groups (Wurzinger et al. 2011). These CBBP practice record keeping, selection, avoidance and inbreeding and group based marketing. While less formalized, some small farmers' groups (Grupo de pequeños productores) often accomplish similar purposes. In all these combinations of standard animal genetic practices combined with marketing and health programs have worked well but their sustainability in some regions is tenuous given their cost. Again human capacity building (see below) would aid in training small holders and adopting approaches like train the trainer to further the spread of knowledge would be useful.

Improvement with genetic markers and genomic approaches. The $21^{\text {st }}$ century has been marked with the use of molecular genetic markers and now advances in genomics including sequencing, development of large panels of single nucleotide polymorphisms (SNPs), genome wide association studies (GWAS) and employing genomic selection. As Hayes et al. (2013) pointed out, such genomic selection methods are being applied to traits such as milk production in cattle and feed efficiency in chickens, cattle and pigs and could eventually be applied for traits like reduced methane production in cattle. This fine tuning of selection approaches using genomics has come after many decades of the use of conventional genetic methods and has been developed in systems that support animal identification, recording of phenotypes, and good-paying reward systems for increased production.

Unlike milk production in many developed counties, where cows may produce over $100 \mathrm{~L}$ a day, cows in some developing countries can only produce 1-10 L per day. Of course, interventions that increase the amount and quality of feed and availability of water will be major inputs. With better environmental conditions, improved genetic quality of livestock certainly will be advantageous. This has been demonstrated in countries as diverse as India and Ethiopia (Duncan et al. 2013) and could potentially help address, at least in part, the problems encountered by the introduction of improved breeds from the developed world. Improvement through use of genetically superior breeds generally has been perceived as a failure for small holders, with genetic potential being lost in these poorer or more challenging environments. A better understanding of the genetic architecture and strengths of many exotic breeds but also local breeds, and how they are adapted to their environment, through genomics also may allow a more precise use of exotic germplasm to support these improvement efforts.

Use of large SNP panels to identify signatures of artificial and natural selection, of benefit in different production settings and environments, are underway in many studies. SNP panels also have been used to examine genetic differences between cattle in large production herds compared to those of small holders (Gorbach et al. 2010). All these genomic approaches are likely to lead to discovery of genes or genomic regions associated with increased production for breeds in harsh environments in developing countries. An initial example is preliminary work on Gir cattle from Brazil, where some signatures of selection were in regions of the genome known to contain genes that might be associated with adaptation (Liao et al. 2013). Use of genomics in other Latin American cattle production has also been well explored (Montaldo et al. 2012). Combined with information from similar discoveries using improved breeds, genomic solutions should be very useful for improving production efficiency and outputs, provided breeding systems can 
be developed to ensure application of the improved genetics. This research requires significant resources which may not be available in the regions where the results need to be applied. However, partnerships addressing these questions can help develop the skills required that researchers can then take back to help implement practical solutions.

Improvement in traits affecting climate resilience. Improving standard production traits, such as milk production, growth rate, and production of total animal protein, are important. However, climate change is expected to affect animal production, especially for small holders. These effects are likely to include limited feed, increased drought, changes in disease prevalence and increased incidence of heat stress. Heat stress reduces production efficiency, decreases product outputs, increases animal welfare issues and is expected to result in significant death losses in some cases (Baumgard and Rhoades 2013). For heat stress, short-term solutions include building shelters and providing cooling mechanisms. However, in many developing countries facilities and management are often limited, so solutions to combat climate change can be difficult. Even so, efforts are likely to be needed on all fronts, and this aspect cannot be ignored, especially in the short term. In fact resistance to temperature stress in general including cold stress may become more important as climate change may result in more variation or more extremes weather with drier areas becoming drier or hotter and wet areas wetter or colder at least seasonally (Trenberth 2011).

Long-term genetic solutions may require the use of genomics to identify signatures of selection related to temperature stress (for example heat in Bos indicus, Liao et al. 2013) and individual genes associated with mechanisms to combat climate issues. Research examining climatic stress in sheep and goats (Kim et al. 2014) has revealed possible signatures of selection.

Severity of disease and disease prevalence also are likely to be affected by climate change through the impact of stresses as well as through changes in the geographical range of diseases (Purse et al. 2005). Long-term solutions also may benefit from genomic approaches. Most disease resistance research efforts have been devoted to diseases existing in modern production settings, but examples do exist in the developing world, such as resistance to lentiviruses in small ruminants (White and Knowles 2013) that demonstrate the possible power of modern genomic approaches. Other examples include the long-term research effort devoted to examining differences among native breeds of cattle in Africa for resistance to Trypanosoma congolense infection, which causes sleeping sickness (Noyes et al. 2011). A novel variation on this approach is to examine diseases that exist in the wild without serious consequences, but that affect similar domesticated species (see below in terms of genetic modification/editing). In all such cases, sequencing of genomes and comparisons among resistant and susceptible breeds or resistant and susceptible species offers hope in understanding the underlying genes responsible for resistance.

Characterization and management of genetic resources. Modernization and genetic improvement of many livestock species has led to a limited number of breeds being used in most production settings and increased losses of local native breeds. The FAO estimates that there are 1491 (20\%) breeds at risk worldwide (FAO 2007). Genomic tools have been used to measure genetic diversity and population structure in many studies. This work has been done in cooperation with scientists from institutions in the developed world and hence may reflect their own approaches and biases. It has been proposed that such genomic knowledge would be useful for designing effective strategies for management and conservation of farm animal genetic resources (FAO 2007). Measures of allelic differences between populations (i.e., Fst) often have been employed using a limited number of highly polymorphic microsatellites which have been less expensive for developing country research budgets. However, the advent of genome re-sequencing and the production of thousands of SNPs, and the subsequent development of SNP chips, have allowed researchers to use them for genetic diversity and GWAS. Researchers are now more effectively comparing breeds/populations from different geographical regions (sometimes called landscape genomics). In turn, this should provide them with more accurate measure of genetic diversity, architecture and perhaps natural selection for local environments. Although signatures of selection relating to local adaptations may be identified (see below), in general these studies need to be allied to efforts to characterize the aspects of performance in these environments. Clearly, if breed conservation is to be maintained, then cost of genomic evaluation efforts must be funded and performance of conserved breeds must be of economic value to all livestock producers. Focusing on local solutions may 
improve the chance of success of this approach, especially if the research involves those who are directly involved in managing these breeds.

\section{Reproductive Technologies and Interventions}

Reproductive technologies have greatly advanced animal improvement by generally making it possible to use fewer select animals to produce the next generation. In doing so, the genetically superior animals can be used more widely. For small holders, especially dairy producers, use of artificial insemination and superior bulls for milk production could greatly increase production ability. Of course, this must be coupled with improvements in the production environment. Other advances, such as embryo transfer (ET) can allow for the ability to multiply significant numbers of superior embryos for production. In many countries in South and Central America, increased use of artificial insemination and ET have been very successful. Development of CBBPs or farmer cooperatives to help in semen distribution can certainly be useful for small producers and artificial insemination has been successfully adopted in rural situations in India. Despite the big change in practice required, use of artificial insemination by rural producers, grew throughout India as a result of Operation Flood with about 18 million inseminations performed annually in 1996 at the village-level by paraprofessionals, who were supported by trained professionals running semen banks and stud stations. This grew to 34 million by 2007 (Cunningham 2009). Many production systems for cattle are meat and milk and hence extra male calves have value. However, sexed semen would be particularly beneficial for small producers trying to produce only heifers to increase milk production. Other technologies such as timed insemination and synchronized estrus have benefit for many larger operations, but may in the near future be useful for small producers who wish to share males for breeding.

\section{Disease Reduction and Health Improvement}

Most animal production units in the developing world are operated by small holder farmers with extremely limited resources and limited access to proper affordable veterinary care. Many shelters are poor and have little or no biosecurity enforcement and poor environmental control. In many cases animals are not separated from their waste and live on earthen floors which allows continual parasite problems. Removal of these problems and increased biosecurity will go a long way towards increasing animal production efficiency for small holders. Many of these diseases also are zoonotic, and hence as many as a 1 billion livestock keepers are at risk worldwide (Grace et al. 2012). Although some of the production gap will be addressed through large scale intensification and increased biosecurity (e.g. as seen in Brazil and China), a greater proportion is likely to be delivered by small holders. Therefore, protection from pathogens is very important and requires accurate assessment of the pathogen itself as well as the possible development of an inexpensive and efficacious vaccine that can be delivered in these environments and situations.

The use of genomics, in particular, new methods of sequencing, to more effectively identify the strain of a pathogen and to help in the isolation of specific antigens for development of new and more effective vaccines has been proposed. Tracing the source of the pathogen and monitoring its spread over regions can also be effective in future disease prevention strategies. Efforts are underway to develop simply driven low cost diagnostic testing for human disease and these may find application in livestock production (Taylor et al. 2014).

\section{Genetic Engineering of Livestock}

The introduction of genetically modified crops (GMOs) has revolutionized plant agriculture, at least in some parts of the world. Even so, there continues to be a fear of accepting the technology, especially in Europe and even for a product such as Golden Rice, which was designed to help improve the lives of the poor in the developing world. Rejection of the engineering of food animals has been even greater for a number of reasons, including animal welfare. However, genetic manipulation provides the potential to make genetic changes that may be impossible through other approaches, at least in relatively short time frames. An area of great opportunity and potential benefit for this technology is therefore in animal health and disease resistance. For example, the development of chickens resistant to avian flu or those that reduce the spread of the disease, could have a huge impact on the economics and supply of chicken as well as potentially playing a significant role in reducing the threat of a flu pandemic (Lyall et al. 2011). Other opportunities include the production of Trypanomiasis-resistant cattle 
or animals resistant to African Swine Fever which have the potential to revolutionize the lives of small holders in parts of Africa where these diseases are endemic.

The development of new tools and technologies mean that these changes can be introduced more precisely and more efficiently than ever before (Tan et al. 2012). These approaches have been used recently to replace the RELA locus of domestic pigs with that from warthogs associated with resilience to African Swine Fever (Lillico et al. 2016). Results from genomic studies, for example those investigating different breeds and species, will provide new targets to help improve the suitability of genetics for many of the environmental challenges faced in the developing world and can remove some of the problems in organizing improved animal production. However, it will not be enough that we can create these potential solutions. In addition, proactive efforts to win approval will be required to ensure the acceptability of such solutions where they are needed.

\section{Implementation of Technology Solutions}

Criteria have been suggested to evaluate the performance of livestock-related projects. These include "1) relevance of projects to the poor, and to national and local development objectives; 2) extent of satisfaction of project objectives through successful completion of activities; 3 ) sustainability in delivery of project benefits; 4) market access and utilization enabled by the project; and 5) value addition enabled by the project" (Wanyoike and Baker 2013). Such criteria should be applied to applications of technology to livestock improvement and production.

How will this be achieved? A large dairy cattle evaluation project, funded by the Bill and Melinda Gates Foundation, is underway using SNP genotyping panels to determine genomically what is the best breed/genotype combinations for production in subSaharan Africa, and recently has been extended to include Ethiopia and Tanzania. Similar efforts are underway for goats through partnerships with European and US scientists. Assuming that the best genotypes can be identified, how then will they be delivered? In the developed world, recording systems, animal identification, breeding companies and artificial insemination companies exist to deliver improved sires, provide embryos for transfer or make planned matings. Such industrial infrastructure, as has been discussed, is lacking in the poorest countries of the developing world, even though governments attempt to put this infrastructure in place. Even if breeding systems can be developed and semen from genomically improved sires become available, improvements may fail to reach small holders due to lack of physical infrastructure including insufficient stores of liquid nitrogen, artificial insemination tools, quality roads and transportation services. Clearly industry and government need to work together to support such efforts.

Use of technology to develop better vaccines offers real promise, but impediments do exist in many poor developing countries. Because many vaccines require refrigeration and cold chain storage is unlikely in many developing countries, therefore vaccines not requiring refrigeration ensure higher use and efficacy. The manufacturing of high-quality biologics and vaccines also may be an impediment. These aspects also are true for human health, and attention should be paid to understanding how these issues are being addressed to transfer learning to agricultural issues. Finally, many of the very poor developing countries may view technology solutions as genetic engineering and may have policies that are not supportive. Similar problems may be encountered for technologies such as genome editing, which some researchers consider to be outside of the definition of genetically modified organisms (GMOs). These are the considerations that need to be dealt with proactively by cross-disciplinary teams and by utilizing new opportunities for communicating with consumers. In summary, if technology improvements are to be realized, infrastructure and policy considerations, as well as communication, need to be included in long range planning and implementation.

\section{Other Considerations}

Research funding. The agricultural research enterprise in most developed countries has limited funding but far outpaces that of developing countries. It has been estimated that high- and middle-income countries account for nearly $90 \%$ of all investment in agricultural research and development (Beitema and Stads, 2010). Such funding often is a mix of basic and applied research efforts. This is complicated by the realization that larger investments are often directed toward the plant sciences than the animal sciences. This fact is even more pronounced in research devoted to agricultural improvement in the poorer developing countries (excluding Brazil and China). While not 
officially published or known it has been estimated that less than $20 \%$ of the several agencies and foundations (e.g. US Agency for International Development and the Bill and Melinda Gates Foundation) agricultural research efforts are devoted to animal-related research. The Bill and Melinda Gates Foundation recently created an enlarged team dedicated to livestock and revised its priorities.

Data from other countries and donors are limited, but until there are increases in animal agricultural research funding, improvements, especially as they relate to animal production research for developing countries, are likely to lag. Even so, countries such as the US, Canada and the UK are beginning to recognize the importance of food security and that this extends beyond their own borders. After all, having sufficient food is one of the elements that contribute to stability, and ultimately security, across today's connected world more than ever.

Gender and youth: In many countries, women and youth provide major inputs to livestock production, especially in small herds and flocks and for smaller livestock species. USAID has long suggested that in many countries more involvement by women and fairer production practices would allow for production increases as large as $20-25 \%$. Reduction of inequalities therefore should be seen as a means to increase productivity at the household and farm levels. Research to examine and understand gender differences in each country and culture therefore has relevance (Farnworth 2015) and should be considered. Improvement of women's empowerment has also shown to benefit household nutrition and economic security. Finally, most Latin America countries have much large numbers of young people. Exciting possibilities exist if the livestock sector is expanding and would help to limit migration to urban areas.

Furthermore, as the future of the livestock sector depends on well trained people efforts to expand farmer to farmer training to youth and efforts by outstanding universities like Zamorano University in Honduras can only help to positively impact livestock production.

Need for human and institutional capacity building. Technological advances in nutrition, reproduction, health and genomics have been quickly adopted in the developed world. Such developments require well- trained scientists and laboratories to support their activities, and these advances traditionally have been supported by and developed in strong universities and government agricultural research units.

In the developing world, large investments in higher education were made from the 1960s to the 1990s by donors such as USAID, the Rockefeller Foundation and the World Bank, but in recent years investments have declined and the negative effects are obvious. In many cases, with the numbers of students in these countries increasing coupled with lack of support, quality has declined (Mouton 2008b). The National Agricultural Research Systems (NARSs) or other government research organizations, called National Agricultural Research Institutes (NARIs), in many developing countries provide the majority of the agricultural research (Pardey and Alson, 2010). The NARS and NARIs both suffer in many countries from aging staff, few female staff, limited funding and old facilities (Pardey and Alson 2010). Although international research organizations, such as the Consultative Group on International Agricultural Research (CGIAR) cover many important crops and animal issues they cannot make up for limited institutional and human capacity deficiencies. Again, these issues have been recognized and are at least being built into plans, especially in funding from agencies like USAID in the US.

The advancement and adoption of modern technologies will require research institutions and an increasing number of significantly better trained individuals with advanced degrees, and such training likely will need to occur in the US and other developed countries or be addressed by new ways of developing these resources in situ. This also will necessitate that these trained scientists return to and/or remain in their home countries to help train small holders, food producers and the next generation of researchers and farmers. There are opportunities to use new communication tools to support these efforts as well as to identify existing approaches that have worked in the past. Investment in economic research that considers barriers to adoption as well as potential return on investment should be encouraged to help improve the chance of successful outcomes.

Other activities that could advance the ability to employ modern technologies include technical assistance, mentoring, workshops, conferences (like Ensminger conferences), study tours (especially those aimed at providing training of future trainers), 
institutional linkages and increased access to the internet for webinars, publications and technical information. Many donors are increasing support for such capacity-building activities, although support of those activities related to livestock research lags behind that of crops. These and other issues are beginning to be recognized along with the need for developments and initiatives that are "relatively simple, cheap and low-risk" for livestock producers.

Market access and inputs. Even with advanced technology, improved nutrition and access to better health care, small holders still suffer from lack of information and market access. This is especially true for women producers. Modification of policies (and customs) to allow research centers and universities to encourage exchange of ideas and inputs will speed this process. Government intervention to insure proper roads, facilities to slaughter animals and provide safe post-harvest handling are all required. This will even the playing field for all farms, small and large, alike.

\section{Conclusions}

By 2050, the need to feed over 2 more billion people will require $70 \%$ more food production, and there will be a significant increase in demand for animal sourced foods. Limitations in land and water and climate change issues will challenge livestock producers, especially small holders worldwide. The biological sciences in the $21^{\text {st }}$ century already have been transformed by new technologies and their applications to agriculture. However, these changes have affected largely only those who live in the developed world. Employing technology generated solutions to increase livestock production efficiency in the developing world to meet these demands will be required. Opportunities for such solutions are many and include all aspects of livestock production.

Delivery of many of these solutions in these production settings, especially in the case of breeding programs involving improved livestock, have yet to be developed and will require novel solutions. Although, there has been a general belief in the power of technology to rescue humanity, time is short and there is evidence that attitudes are changing. Technology itself will not provide all of the answers. Instead, we need to look at all aspects, from animal production to food distribution and food waste, and international trade. Additionally, improved development of human and institutional capacities also will be required. The challenges are many, but the need to feed people in each country and overall a hungry world will require that all animal producers, scientists, social scientists, funding agencies and policy makers work together to find solutions.

Acknowledgements. The author acknowledges that many of the ideas have been previously expressed in Rothschild and Plastow (2014). Suggestions and comments from colleagues at the University of Alberta, lowa State University and the U.S. Agency for International Development are appreciated. Financial support provided by the Ensminger Fund, the College of Agriculture and Life Sciences, lowa State University, State of lowa and Hatch funding and Alberta Innovates BioSolutions is appreciated.

\section{References Cited}

Beitema, N., and G.J. Stads. 2010. Public Agricultural R\&D Investments and Capacities in Developing Countries: Recent evidence for 2000 and Beyond. Note prepared for global conference on Agricultural Research (GCARD), Montpellier, 27-30, Washington, DC: IFPRI.

Baumgard, L.H., and R.P. Rhoads. 2013. Effects of heat stress on postabsorptive metabolism and energetics. Annual Review Animal Biosciences 1: 311-337.

Cunningham, K. 2009. Rural and Urban Linkages: Operation Flood's Role in India's Dairy Development. International Food Policy Research Institute Discussion Paper 00924 www.ifpri.org

Delgado, C., M. Rosegrant, H. Steinfeld, S. Ehui, and C. Courbois. 1999. Livestock to 2020: the next food revolution. IFPRI Food, Agriculture, and the Environment Discussion Paper 28. Washington, D.C. (USA): IFPRI

Duncan, A.J., N. Teufel, K. Mekonnen, V.K. Singh, A. Bitew, and B. Gebremedhin. 2013. Dairy intensification in developing countries: Effects of market quality on farmlevel feeding and breeding practices. Animal 7: 20542062.

Farnworth, C.R., P.Kantor, F. Kruijssen, C. Longley, and K.E. Colverson. 2015. Gender integration in livestock and fisheries value chains: Emerging good practices from analysis to action. International Journal of Agricultural Resources, Governance and Ecology 11 (34): $262-279$.

Fix, J.S., J.P. Cassady, E. van Heugten, D.J. Hanson, and M.T. See. 2010. Differences in lean growth performance of pigs sampled from 1980 and 2005 commercial swine fed 1980 and 2005 representative feeding programs. Livestock Science 128: 108-114. 
Food and Agriculture Organization. 2007. The state of the world's animal genetic resources for food and agriculture. $\mathrm{ftp}: / / \mathrm{ftp}$. fao.org/docrep/fao/010/a1250e/a1250e.pdf

Gorbach, D.M., M.L. Makgahlela, J. Reecy, S.J. Kemp, I. Baltenweck, R. Ouma, O. Mwai, K. Marshall, B. Murdoch, S. Moore, and M.F. Rothschild. 2010. Use of SNP genotyping to determine pedigree and breed composition of dairy cattle in Kenya. Journal of Animal Breeding and Genetics 127:348-351.

Grace, D., F. Mutua, P. Ochungo, R. Kruska, K. Jones, L. Brierley, L. Lapar, M. Said, M. Herrero, P.M. Phuc, N.B. Thao, I. Akuku, and F. Ogutu. 2012. Mapping of poverty and likely zoonoses hotspots. Zoonoses Project 4. Report to the UK Department for International Development. Nairobi, Kenya: ILRI.

Gupta, S. 2016. Clever eating. Nature 531: S12-13.

Havenstein, G., P.R. Ferket, and M.A. Qureshi. 2003. Growth, livability, and feed conversion of 1957 versus 2001 broilers when fed representative 1957 and 2001 broiler diets. Poultry Science 82:1500-8.

Hayes, B.J., H.A. Lewin, and M.E. Goddard. 2013. The future of livestock breeding: genomic selection for efficiency, reduced emissions intensity, and adaptation. Trends in Genetics 29: 206-14.

Hume, D.A., C.E. Whitelaw, and A.L. Archibald. 2011. The future of animal production: improving productivity and sustainability. The Journal of Agricultural Science 149: Supplement S1 9-16.

Ingram, J., and D. Liverman. 2010. Food security and global environmental change. Earthscan, London

International Chicken Genome Sequencing Consortium. 2004. Sequence and comparative analysis of the chicken genome provide unique perspectives on vertebrate evolution. Nature 432: 695-716.

Kim, E.S., A.R. Elbeltagy, A.M. Aboul-Naga, B. Rischkowsky, B. Sayre, J.M. Mwacharo, and M.F. Rothschild. 2015 Multiple genomic signatures of selection in goats and sheep indigenous to a hot arid environment. Heredity 116: 255-264.

Liao, X., F. Peng, S. Forni, D. McLaren, G. Plastow, and P. Stothard. 2013. Whole genome sequencing of Gir cattle for identifying polymorphisms and loci under selection. Genome 56: 592-598.

Lillico, S.G., C. Proudfoot, T.J. King, W. Tan, L. Zhang, R. Mardjuki, D.E. Paschon, E.J. Reber, F.D. Urnov, A.J. Mileham, D.G. McLaren, and B.A. Whitelaw. 2016 Mammalian interspecies substitution of immune modulatory alleles by genome editing. Scientific Reports 6:21645.

Ludu, J., and G. Plastow. 2013 Livestock and the promise of genomics. Genome 56: 556-566
Lyall, J., R.M. Irvine, A. Sherman, T.J. McKinley, A. Nunez, A. Purdie, L. Outtrim, I.H. Brown, G. Rolleston-Smith, H. Sang, and L. Tiley. 2011. Suppression of avian influenza transmission in genetically modified chickens. Science 331: 223-226.

Montaldo, H.H., E. Casas, J.V.S. Ferraz, V.E. Vega-Murillo, and S.I. Romain-Ponc. 2012. Opportunities and challenges from the use of genomic selection for beef cattle breeding in Latin America. Animal Frontiers 2: 2329.

Moutin, J. 2008. Africa's science decline: The Challenge of building scientific institutions. Global Education 30(3). 46-51. Cambridge: Harvard International Review

Noyes, H., A. Brass, I. Obara, S. Anderson, A.L. Archibald, D.G. Bradley, P. Fisher, A. Freeman, J. Gibson, M. Gicheru, L. Hall, O. Hanotte, H. Hulme, D. McKeever, C. Murray, S.J. Oh, C. Tate, K. Smith, M. Tapio, J. Wambugo, D.J. Williams, M. Agaba, and S.J. Kemp. 2011. Genetic and expression analysis of cattle identifies candidate gene in pathways responding to Trypanosoma congolense infection. Proceedings of the National Academy of Science 108: 9304-9309.

Pardey, P., and J.M. Alston. 2010. US agricultural research in a global food security setting. A report of the CSIS task force on food security. Washington, DC Center for Strategic and International Studies.

Purse, B.V., P.S. Mellor, D.J. Roger, A.R. Samuel, P.C. Mertens, and M. Baylis. 2005. Climate change and the recent emergence of bluetongue in Europe. Nature Reviews Microbiology 3:171-181

Rothschild, M.F., and H. Steinfeld. 2014. Livestock crucial in hunger equation. Science 345: 1254.

Rothschild, M.F., and G.S. Plastow. 2014. Applications of genomics to improve livestock in the developing world. Livestock Science 166:78-83.

Smith, J., K. Soanes, D. Grace, S. MacMillan, S. Taeawali, and M. Herrero. 2013 beyond milk, meat and eggs: Role of livestock in food and nutrition security. Animal Frontiers 3. 6-13.

Tan W.S., D.F. Carlson, M.W. Walton, S.C. Fahrenkrug, and P.B. Hackett. 2012. Precision editing of large animal genomes. Advances in Genetics 80: 37-97.

Taylor, B.W., A. Howell, K.A. Martin, D.P. Manage, W. Gordy. S.D. Campbell, S. Lam, A. Jim, S.D. Polley, R.A. Samuel, A. Atrazhev, A.J. Stikel, J. Birungi, A.K. Mbonye, L.M. Pilarski, and S.K. Yanow. 2014. A lab-onchip for malaria diagnosis and surveillance. Malaria Journal 13:179

Thorton, P.K. 2010. Livestock production: recent trends, future prospects. Philosophical Transactions of the Royal Society B 365:2853-2867.

Trenberth, K.E. 2011. Changes in precipitation with climate change. Climate Research 47: 123-138. 
Wanyoike, F., and D. Baker. 2013. Pro-poor development performance of livestock projects: analysis and lessons from projects' documentation. Development in Practice 23, 889-907, http://dx.doi.org/10.1080/09614524.2013.811470

White, S.N. and D.P. Knowles. 2013. Expanding possibilities for intervention against small ruminant lentiviruses through genetic marker-assisted selective breeding. Viruses 5: 1466-1499.
World Bank. 2009. Minding the stock: bringing public policy to bear on the livestock sector. Report no. 44010-GLB. Washington, DC.

Wurzinger, M., J. Solkner, and L. Iniquez. 2011. Important aspects and limitations in considering community-based breeding programs for low-input smallholder livestock systems. Small Ruminant Research 98:170-175.

Received for publication on March 21, 2016.

Accepted for publication on July 7, 2016 